king lists: Ezana and Zezana are the same persons as 'Abreha and 'Asbeha. In this way epigraphic evidence and indigenous tradition find mutual confirmation.

(Communicated by E. Ullendorff)

\title{
Use of Films in Mass Education and Colonial Development
}

Two of the leading organizations in Great Britain concerned with educational and documentary films have recently initiated large-scale projects of research into the problems and potentialities of the use of films in Mass Education and in Colonial Development. Both organizations will pay particular attention to the needs and problems of African territories.

The Scientific Film Association, which is well known for the important work it has done during the last five years in promoting the production and the use of scientific films in Great Britain, is concentrating on the problem of Mass Education. The S.F.A. International Committee has begun by establishing a liaison with the Fundamental Education section of U.N.E.S.C.O. and has also invited African students studying education and science in this country to co-operate in the research project. The collection of all available information is well in hand, and it is hoped shortly to produce a series of reading lists and information statements to form the basis for further work. The Committee will be considerably assisted in its investigation by the close connexions which it has with the International Scientific Film Association, to which are affliated scientific film movements all over the world.

The other organization working on this question is the newly formed British Documentary, a body which is broadly representative of the documentary film industry as a whole, embracing as it does all those associated in any aspect of the production and distribution of this type of film. The Working Party on Films and Colonial Development set up by British Documentary has outlined a scheme of work covering almost every aspect of the subject. Surveys are to be prepared on the following topics : the policy of individual powers responsible for undeveloped or colonial territories; Censorship Regulations in Colonial Areas; Commercial Cinemas in Colonial Areas; Methods of Production of Films for Colonial Areas; the Financing of Films for Colonial Areas; Distribution and Use of Films; the Training of Native Technicians and Projectionists; Films Relating to Colonial Areas; Analysis of Audience Groups on a Cultural and Ethnological Basis; Recommendations on Subjects for Films; Psychological Problems; Economic and Social Problems.

Both organizations will work closely together in order to avoid duplication of effort, and it is hoped that that this co-operation will lead, at a later stage, to a common working party. It is certain that the efforts of British Documentary and the Scientific Film Association will help to advance understanding of the use of film as a medium for the development of colonial peoples, and that the surveys proposed will contribute towards the solution of the great problems which these two bodies have undertaken to study.

(Communicated by H. G. A. Hughes)

\section{A New Technique in Grammatical Studies}

Some years ago Father Wanger, the Zuluist, made a plea, which has been echoed in many quarters, that the grammar of a Bantu language should be written from the Bantu point of view and not pressed into the frame of Indo-European languages. The Rev. E. W. Price has made this his aim in his study of Ngombe, ${ }^{I}$ the northernmost of the central Bantu languages. Abandoning the traditional terminology, Mr. Price has adapted the technique developed at the School of Oriental and African Studies by Dr. Malcolm Guthrie.

I Ngombe Grammar, by E. W. Price, foreword by Professor Ida C. Ward. Duplicated. Pp. 88. 